Federal Reserve Bank of Dallas

Globalization and Monetary Policy Institute

Working Paper No. 82

http://www.dallasfed.org/assets/documents/institute/wpapers/2011/0082.pdf

\title{
Oil Shocks through International Transport Costs: Evidence from U.S. Business Cycles ${ }^{*}$
}

\author{
Hakan Yilmazkuday \\ Florida International University
}

June 2011

\begin{abstract}
The effects of oil shocks on output volatility through international transport costs are investigated in an open-economy DSGE model. Two versions of the model, with and without international transport costs, are structurally estimated for the U.S. economy by a Bayesian approach for moving windows of ten years. For model selection, the posterior odds ratios of the two versions are compared for each ten-year window. The version with international transport costs is selected during periods of high volatility in crude oil prices. The contribution of international transport costs to the volatility of U.S. GDP has been estimated as high as $36 \%$ during periods of oil crises.
\end{abstract}

JEL codes: E32, E52, F41

* Hakan Yilmazkuday, Department of Economics, Florida International University, Miami, FL 33199. 305-348-2316.skuday@gmail.com. The views in this paper are those of the author and do not necessarily reflect the views of the Federal Reserve Bank of Dallas or the Federal Reserve System. 


\section{Introduction}

Figure 1 shows the relation between the U.S. business cycles and the volatility of crude oil prices for ten-year moving windows. For each ten-year window, the solid line represents the number of NBER recession quarters, and the dashed line represents the coefficient of variation in oil prices. ${ }^{1}$ The two series seem to move together with a correlation coefficient of 0.54 . This figure raises the question of whether oil prices have any significant effects on the business cycles. Many earlier studies have attempted to answer this question. Among many others, Kim and Loungani (1992) have shown in a neoclassical model that oil price shocks could explain only a modest component of the variance of U.S. output growth. Rotemberg and Woodford (1996) have suggested in their markup pricing model that a $10 \%$ increase in energy prices could lead to a $2.5 \%$ drop in output after 6 quarters. Finn (2000) has shown that capital utilization is another channel that would provide similar results as in Rotemberg and Woodford (1996). Bernanke et al. (1997) have claimed that changes in oil prices lead the Federal Reserve to raise interest rates (in order to control inflation), which, in turn, cause downturns; hence, monetary policy is another channel through which oil prices can affect the business cycles. Similarly, Barsky and Kilian $(2002,2004)$ have argued that a monetary expansion was the cause of much of the 1973-74 oil price increase and the decline in output afterwards. Leduc and Sill (2004) have shown through capital utilization and sticky prices that monetary policy contributes about 40 percent to the drop in output following a rise in oil prices. Hamilton and Herrara (2000), Dotsey and Reid (1992), Hoover and Perez (1994), Ferderer (1996), Brown and Yücel (1999), and Davis and Haltiwanger (2001) have all shown empirically that, compared to the monetary policy, the oil prices have been more influential on the business

\footnotetext{
${ }^{1}$ Business cycle dates have been obtained from http://www.nber.org/cycles.html. Crude oil prices have been obtained from http://www.ioga.com.
} 
cycles. Bresnahan and Ramey (1993), Bohi (1991), Lee and Ni (2002), Davis and Haltiwanger (2001), and Keane and Prasad (1996) have focused on the frictions in reallocating labor or capital across different sectors that may be differentially affected by an oil shock.

This paper mostly belongs to the part of the literature that focuses on the effects of oil price shocks on the business cycles through the CPI inflation rate. As Hamilton (2005) nicely puts, the inflation rate is governed by monetary policy, so, ultimately, this is a question about how the central bank responds to the oil price shock. Hooker (2002) has found evidence that oil shocks made a substantial contribution to U.S. core inflation before 1981 but have made little contribution since, consistent with the conclusion of Clarida, Galí and Gertler (2000) that U.S. monetary policy has become significantly more devoted to curtailing inflation. Within this picture (i.e., the effects of oil prices on the business cycles through the inflation rate), none of the papers mentioned above have investigated the international-transport-cost channel of oil prices. In particular, in a world where consumer utility depends on domestically-produced goods and internationally-imported goods, the inflation rate depends on the price of domestically-produced goods and the price of internationallyimported goods that includes international transport costs. A natural question arises: What are the effects of oil price shocks on the business cycles through international price differences (i.e., short-term deviations from the Law of One Price) measured by such international transport costs? This paper attempts to answer this question by estimating two versions of a standard DSGE model, with and without international transport costs, using the U.S. quarterly data. In the version with transport costs, the optimization of individuals and firms in a flexible price equilibrium setup result in having the effects of international transport costs in the IS equation, the Phillips curve, the terms of trade expression, the monetary policy rule, and the CPI inflation rate. The structural estimation is achieved by a Bayesian approach for each ten-year window between 1957-2010 to investigate nonlinearities in the U.S. economy caused by oil price shocks through time. For each 
ten-year window, the posterior odds ratios of the two versions of the model are compared for model selection. The results suggest that a necessary condition for the version of the model with transport costs to be selected is to have a coefficient of variation in crude oil prices of above 0.25 over a ten-year period. Although the average contribution of international transport costs to the volatility of U.S. GDP is estimated about $3 \%$ for the whole sample period, the contribution is up to $36 \%$ during periods of oil crises. According to the structural estimation results, the Federal Reserve has used interest rates as a policy tool during periods of oil crises mostly to stabilize output rather than the inflation rate or the interest rate.

The rest of the paper is organized as follows. Section 2 gives a summary of the model. Section 3 introduces the data and the estimation methodology. Section 4 depicts the estimation results. Section 5 concludes. The detailed derivation of the model, together with its implications, is given in the Appendices.

\section{Model}

The model is a version of Gali and Monacelli (2005) with the addition of international transport costs at the final goods level. The model consists of a forward-looking IS-equation and a forwardlooking Phillips curve, together with a monetary policy described by an interest rate rule and a terms-of-trade expression. The detailed derivation of model is given in Appendix A.

The IS curve is given by

$$
y_{t}=E_{t}\left(y_{t+1}\right)-\left(i_{t}-E_{t}\left(\pi_{H, t+1}\right)\right)+E_{t}\left(\Delta \tau_{t+1}\right)
$$

where $y_{t}$ is the output, $i_{t}$ is the annual nominal interest rate, $\pi_{H, t}$ is the annual inflation of homeproduced goods, $\tau_{t}$ represents symmetric transport costs on internationally traded (i.e., both exported and imported) final goods, $E_{t}$ is the expectation operator, and $\Delta$ is the first-difference 
operator.

The Phillips curve is given by

$$
\pi_{H, t}=\beta E_{t}\left(\pi_{H, t+1}\right)+\lambda_{x} x_{t}
$$

where $\lambda_{x}=\frac{(1-\alpha)(1-\alpha \beta)}{\alpha}, \alpha$ is the probability that a firm does not change its price within a given period (i.e., price stickiness), $\beta$ is the discount factor, $x_{t} \equiv y_{t}-z_{t}+\tau_{t}$ represents the output gap under a flexible price equilibrium where $z_{t}$ is the level of technology. As is shown in Appendix $\mathrm{B}$, stabilizing the output gap (the gap between actual and natural output) is not equivalent to stabilizing the welfare-relevant output gap (the gap between actual and efficient output). Hence, there is no divine coincidence in the model of this paper mentioned by Blanchard and Gali (2007).

The nominal interest rates are determined by a Taylor rule:

$$
i_{t}=\left(1-\rho_{i}\right)\left(\chi_{\pi} E_{t}\left(\pi_{t+1}\right)+\chi_{x} E_{t}\left(x_{t}\right)\right)+\rho_{i} i_{t-1}+\varepsilon_{t}
$$

where $\pi_{t}$ is the annual consumer price index (CPI) inflation, $\rho_{i}$ captures the degree of interest-rate smoothing, and $\varepsilon_{t}$ is an exogenous policy shock which can be interpreted as the non-systematic component of monetary policy. The relation between inflation of home-produced goods (i.e., $\pi_{H, t}$ ) and CPI inflation (i.e., $\pi_{t}$ ) is given by:

$$
\pi_{t}=\pi_{H, t}+\gamma\left(\Delta s_{t}\right)
$$

where $\gamma$ is a measure of openness, and $s_{t}$ is the effective terms of trade given by:

$$
s_{t}=\left(i_{t}^{*}-E_{t}\left(\pi_{F, t+1}^{*}\right)\right)-\left(i_{t}-E_{t}\left(\pi_{H, t+1}\right)\right)+E_{t}\left(s_{t+1}-\Delta \tau_{t+1}\right)
$$

where $i_{t}^{*}$ is the annual foreign interest rate, and $\pi_{F, t}^{*}$ is the annual foreign inflation (through imported goods). Since $i_{t}^{*}$ and $\pi_{F, t}^{*}$ appear only in the terms of trade expression, we will combine them under a foreign financial variable, $f_{t}^{*}=i_{t}^{*}-E_{t}\left(\pi_{F, t+1}^{*}\right)$. 
There are three additional independent shocks considered in the model, namely technology, international transport costs, and foreign financial variable:

$$
\begin{gathered}
z_{t}=\rho_{z} z_{t-1}+v_{t}^{z} \\
\tau_{t}=\rho_{\tau} \tau_{t-1}+v_{t}^{\tau} \\
f_{t}^{*}=\rho_{f^{*}} f_{t-1}^{*}+v_{t}^{f^{*}}
\end{gathered}
$$

As is evident, there is no foreign output variable (hence no foreign output shock) in the model. Instead, as shown in Appendix C, the expected change in foreign output is decomposed into the foreign financial variable and transport costs. As discussed in Appendix D, the foreign financial variable also captures any international financial frictions or shocks between home and foreign countries through the exogenous foreign interest rate. Hence, one may expect to have higher contributions of the foreign financial variable and international transport costs on the business cycles, because they may capture such latent variables mentioned above.

As opposed to this paper, many studies have endogenized the deviations from the Law of One price; e.g., Monacelli (2005) has introduced a model with import retailers subject to price rigidities of which versions have been estimated by many studies such as Lubik and Schorfheide (2005) for the Euro Area, Justiniano and Preston (2010) for Canada, Australia and New Zealand, Adolfson et al. (2007) for Sweden; similarly, Gust et al. (2009) have focused on local currency assumptions, non-constant elasticity of demand, or distribution costs; Bridgman (2008) has introduced a model with transportation sector to investigate the expansion of world trade. Nevertheless, the exogeneity of international transport costs is simple and enough for the question asked in this paper, because we only care about the exogenous effects of oil shocks on the U.S. business cycles. 


\section{Data and Estimation Methodology}

The open-economy model is estimated using data on the U.S. economy obtained from International Financial Statistics for the quarterly period over 1957:Q1-2010:Q4. The variables are calculated as percentage deviations from their steady-states to take care of any possible stationarity issues. We use observations on the percentage deviations of real output, CPI inflation, and short-term nominal interest rates from their steady states in annual terms where percentage deviations have been calculated as Hodrick-Prescott filtered versions of seasonally adjusted Real GDP (US\$ at 2005 prices), Consumer price index $(2005=100)$, and Federal Funds Rate.

The estimation is achieved through a Bayesian approach where the choice of priors for the structural parameters plays an important role. Table 1 provides information on prior distributions for all parameters that have been selected as consistent with the existing literature (e.g., see Lubik and Schorfheide, 2007, An and Schorfheide, 2007, and the discussions therein). One important detail is that the model is parameterized in terms of the steady-state real interest rate $r$, rather than the discount factor $\beta$, where $r$ is annualized such that $\beta=\exp (-r / 400)$.

The moving-window estimation is achieved for each ten-year period between 1957:Q1-2010:Q4. To address the question of whether international transport costs are significant in explaining output volatilities, for each ten-year period, two versions of the model, with $\left(\tau_{t}>0\right.$ for all $\left.t\right)$ and without $(\tau=0$ for all $t)$ transport costs, are estimated. For model selection, we assess the hypothesis of $\tau=0$ against the alternative of $\tau_{t}>0$ for all $t$ by computing the posterior odds ratios for each ten-year period. The reader is referred to Lubik and Schorfheide (2007) for technical details related to the calculation of the posterior odds ratio. 


\section{Estimation Results}

\subsection{Model Selection}

Figure 2 shows the selected version of the model (i.e., with or without trade costs) versus the volatility in oil prices for each ten-year period estimated. While the vertical axis on the left shows the volatility in oil prices (measured by the coefficient of variation), the vertical axis on the right shows the selected model by taking a value of 0 for the version of the model with $\tau_{t}=0$ and

a value of 1 for the version of the model with $\tau_{t}>0$. As is evident, the model with positive international transport costs shocks has been selected during periods of high oil price volatility that include the production peak of the U.S. in 1970, the oil crises in 1973 and 1979, the oil glut in 1980s, the 1990 oil price spike occurred in response to the Iraqi invasion of Kuwait, and the 2005 oil price shock. One striking evidence is that a necessary condition for the version of the model with positive international transport costs shocks to be selected is to have a coefficient of variation in crude oil prices above 0.25. Therefore, according to the methodology of this paper and the relation between oil prices and recessions in Figure 1, the U.S. GDP has been affected by international transport costs during period of high oil price volatility. But, how important are these international transport costs? To answer this question, we calculate the variance decomposition of the U.S. GDP for each ten-year window, below.

\subsection{Variance Decomposition of Output}

The variance decomposition of the U.S. GDP through the version of the model with international transport costs (i.e., $\tau_{t}>0$ ) is given in Figure 3. According to this version of the model, on average, about $30 \%$ of output volatility is due to transport costs shocks, $47 \%$ due to foreign financial shocks, $13 \%$ due to technology shocks, and $10 \%$ due to monetary policy shocks. High contributions of 
international shocks, namely transport costs and foreign financial shocks, are mostly attributable to latent variables of foreign output (see Appendix C) and financial frictions (see Appendix D) that show up under either of these two shocks. One striking evidence is that, during the periods of oil crises, the effect of transport costs falls, and the effects of foreign financial and monetary policy shocks increase. Hence, the effects of oil shocks are mostly through international financial markets or the monetary policy rather than the direct effects of oil prices on international transport costs. Another evidence is that technology shocks have a higher contribution on output volatility starting from mid-1980s.

The variance decomposition of the U.S. GDP through the version of the model without international transport costs (i.e., $\tau_{t}=0$ ) is given in Figure 4. According to this version of the model, on average, $63 \%$ of output volatility is due to foreign financial shocks, $13 \%$ due to technology shocks, and $24 \%$ due to monetary policy shocks. Hence, the effect of transport costs on output volatility in the version with transport costs seems to be mostly replaced by either the foreign financial variable or the monetary policy in the version without transport costs. During the periods of oil crises, the effect of foreign financial shocks seems to be higher. Hence, the effects of oil shocks are mostly through international financial markets in this version of the model. As in the model with transport costs, technology shocks have a higher contribution on output volatility starting from mid-1980s.

When we turn back to our question of how important international transport costs are, we combine the variance decompositions of output coming from the two versions of the model. In particular, we know which model is selected by the posterior odds ratio for each ten-year window; by using the variance decomposition of output obtained from the selected model for each ten-year window, we combine the variance decompositions of output in Figure 5. As is evident, international transport costs can contribute to the volatility of output up to $36 \%$ during the periods of oil crises. 
Nevertheless, the average contribution of international transport costs on the volatility of output is about $3 \%$ for the whole sample period; this latter result is consistent with Kim and Loungani (1992) who have shown in a neoclassical model that oil price shocks could explain only a modest component of the variance of U.S. output. In sum, although the effect of international transport costs is minimal during non-crisis periods, the U.S. economy has had experienced significant effects of oil prices on its output through international transport costs during the periods of oil crises.

According to the combined variance decomposition of output, on average, the contributions of foreign financial variable shock, monetary policy shock, technology shock, and international transport shock are $62 \%, 23 \%, 12 \%$, and $3 \%$, respectively, for the whole sample period. Therefore, the direct effects of oil price changes through international transport costs are less than the effects of monetary policy shocks; this result is opposed to studies such as Hamilton and Herrara (2000), Dotsey and Reid (1992), Hoover and Perez (1994), Ferderer (1996), Brown and Yücel (1999), and Davis and Haltiwanger (2001), and it is consistent with studies such as Bernanke et al. (1997), Barsky and Kilian (2002, 2004), and Leduc and Sill (2004). Nevertheless, the biggest effect on output is due to foreign financial shocks which may have also been affected by oil price shocks in an indirect way (e.g., the effects of oil shocks on the rest of the world). Once again, high contributions of international shocks, namely transport costs and foreign financial shocks, are mostly attributable to latent variables of foreign output (see Appendix C) and financial frictions (see Appendix D) that show up under either of these two shocks.

\subsection{Monetary Policy}

The other parameters of the model (i.e., the posterior means as point estimates) have also been obtained through the ten-year window estimations. To save space and focus on the monetary policy through time, we only depict the Taylor rule parameter estimates obtained from the combination 
of the two versions of the model; i.e., each depicted parameter belongs to the model selected by the posterior odds ratio. The estimates of $\chi_{\pi}$ through time are given in Figure 6. As is evident, the response of the Federal Reserve to the deviations of inflation from its target value seems to be negatively related to the volatility of crude oil prices; in other words, during the periods of oil crises, the Federal Reserve has given fewer weight to inflation according to our Taylor rule specification. The estimates of $\chi_{x}$ through time are given in Figure 7 . As is evident, the response of the Federal Reserve to the deviations of output from its flexible-price-equilibrium value seems to be positively related to the volatility of crude oil prices; hence, during the periods of oil crises, which mostly correspond to the recession periods according to Figure 1, the Federal Reserve has given more weight to output gap according to our Taylor rule specification. The estimates of $\rho_{i}$ through time are given in Figure 8 where, as one would expect from an active monetary policy, the interest-rate smoothing is fewer during the times of crises. The last three results suggest that the Federal Reserve has used interest rates as a policy tool during oil crises periods mostly to stabilize output rather than the inflation rate or the interest rate; hence, the Federal Reserve has used interest rates as a policy tool during non-crisis periods mostly to stabilize the inflation rate and the interest rate.

\section{Conclusion}

Two versions of a standard DSGE model, with and without international transport costs, have been estimated by Bayesian techniques to investigate possible effects of oil price shocks on the U.S. business cycles through international transport costs. The estimation has been achieved for each ten-year window between 1957-2010 to investigate nonlinearities in the U.S. economy caused by oil price shocks through time. A necessary condition for the version of the model with positive inter- 
national transport costs shocks to be selected is to have a coefficient of variation in crude oil prices above 0.25 over a ten-year period. Although the average contribution of international transport costs to the volatility of U.S. GDP is about $3 \%$ for the whole sample period, the contribution is up to $36 \%$ during periods of oil crises. The Federal Reserve has used interest rates as a policy tool during periods of oil crises mostly to stabilize output rather than the inflation rate or the interest rate and vice versa.

The results of this paper should be qualified with respect to the structural model employed as it may be misspecified. The results are subject to further improvement; endogenizing transport costs through an oil producing sector/country, introducing capital accumulation, different production sectors, intermediate input trade, and internationally incomplete asset markets would generate richer model dynamics. These are possible topics of future research.

\section{References}

[1] Adolfson, M., J. Linde, M. Villani, (2007), "Forecasting Performance of an Open Economy DSGE Model", Econometric Reviews, 26, 289-328.

[2] An, S. and Schorfheide, F., (2007), "Bayesian Analysis of DSGE Models," Econometric Reviews, 26: 113-172.

[3] Barsky, Robert B., and Lutz Kilian (2002). "Do We Really Know that Oil Caused the Great Stagflation? A Monetary Alternative," in Ben S. Bernanke and Ken Rogoff, eds., NBER Macroeconomics Annual 2001, MIT Press: Cambridge, MA, pp. 137-183.

[4] Barsky, Robert B., and Lutz Kilian (2004). "Oil and the Macroeconomy Since the 1970s," Journal of Economic Perspectives 18, no. 4, pp. 115-134. 
[5] Bernanke, Ben S., Mark Gertler, and MarkWatson (1997), "Systematic Monetary Policy and the Effects of Oil Price Shocks," Brookings Papers on Economic Activity, 1-1997, pp. 91-124.

[6] Blanchard, Olivier and Jordi Gali (2007). "Real Wage Rigidities and the New Keynesian Model," Journal of Money, Credit and Banking, Volume 39, pages 35-65.

[7] Bohi, Douglas R. (1991), "On the Macroeconomic Effects of Energy Price Shocks," Resources and Energy, 13, pp. 145-162

[8] Bresnahan, Timothy F., and Valerie A. Ramey (1993), "Segment Shifts and Capacity Utilization in the U.S. Automobile Industry," American Economic Review Papers and Proceedings, 83, no. 2, pp. 213-218.

[9] Bridgman, B., (2008), "Energy prices and the expansion of world trade", Review of Economic Dynamics, 11, 904-916.

[10] Brown, Stephen P.A., and Mine K. Yücel (1999), "Oil Prices and U.S. Aggregate Economic Activity: A Question of Neutrality," Economic and Financial Review, Federal Reserve Bank of Dallas, (Second Quarter), pp. 16-23.

[11] Clarida, Richard, Jordi Galí, and Mark Gertler (2000), "Monetary Policy Rules and Macroeconomic Stability: Evidence and Some Theory," Quarterly Journal of Economics, 115. pp. 147-180.

[12] Davis, Steven J., and John Haltiwanger (2001), "Sectoral Job Creation and Destruction Responses to Oil Price Changes," Journal of Monetary Economics, 48, pp. 465-512.

[13] Dotsey, Michael, and Max Reid (1992), "Oil Shocks, Monetary Policy, and Economic Activity," Economic Review of the Federal Reserve Bank of Richmond, 78/4, pp. 14-27. 
[14] Ferderer, J. Peter (1996), "Oil Price Volatility and the Macroeconomy: A Solution to the Asymmetry Puzzle," Journal of Macroeconomics, 18 (1996), pp. 1-16.

[15] Finn, Mary G. (2000), "Perfect Competition and the Effects of Energy Price Increases on Economic Activity," Journal of Money, Credit, and Banking, 32, pp. 400-416.

[16] Gali, Jordi. and Tomasso Monacelli (2005), "Monetary Policy and Exchange Rate Volatility in a Small Open Economy", Review of Economic Studies, 72: 707-734.

[17] Gust, C., S. Leduc, N. Sheets (2009), "The adjustment of global external balances: Does partial exchange-rate pass-through to trade prices matter?", Journal of International Economics, $79,173-185$.

[18] Hamilton, J.D. (2005), "Oil and the Macroeconomy," forthcoming in S. Durlauf and L. Blume (eds), The New Palgrave Dictionary of Economics, 2nd ed., Palgrave MacMillan Ltd.

[19] Hansen, Gary D., (1985). "Indivisible labor and the business cycle," Journal of Monetary Economics, vol. 16(3), pages 309-327.

[20] Hooker, Mark A. (2002), "Are Oil Shocks Inflationary? Asymmetric and Nonlinear Specifications versus Changes in Regime," Journal of Money, Credit and Banking 34, pp. 540-561.

[21] Hoover, Kevin D., and Stephen J. Perez (1994), "Post Hoc Ergo Propter Once More: An Evaluation of 'Does Monetary Policy Matter?' in the Spirit of James Tobin," Journal of Monetary Economics, 34, pp. 89-99.

[22] Justiniano, A., B. Preston, (2010), "Monetary Policy and Uncertainty in an Empirical Small Open-Economy Model", Journal of Applied Econometrics, 25, 93-128. 
[23] Keane, Michael P., and Eswar Prasad (1996), "The Employment and Wage Effects of Oil Price Changes: A Sectoral Analysis," Review of Economics and Statistics, 78, pp. 389-400.

[24] Kerr, W., and King, R.G., (1996), "Limits on interest rate rules in the IS model", Federal Reserve Bank of Richmond Economic Quarterly 82: 47-75.

[25] Kim, In-Moo, and Prakash Loungani (1992), "The Role of Energy in Real Business Cycle Models," Journal of Monetary Economics, 29, no. 2, pp. 173-189.

[26] King, R.G., (2000), "The New IS-LM Model: Language, Logic and Limits", Federal Reserve Bank of Richmond Economic Quarterly Volume 86/3.

[27] Leduc, Sylvain and Keith Sill (2004), “A Quantitative Analysis of Oil-Price Shocks, Systematic Monetary Policy, and Economic Downturns," Journal of Monetary Economics, 51, pp. 781808.

[28] Lee, Kiseok, and Shawn Ni (2002), "On the Dynamic Effects of Oil Price Shocks: A Study Using Industry Level Data," Journal of Monetary Economics, 49, pp. 823-852.

[29] Lubik, T.A., Schorfheide, F., (2005), A Bayesian look at New Open Economy Macroeconomics. NBER Macroeconomics Annual 20, 313-366.

[30] Lubik, T.A. and Schorfheide, F., (2007), "Do Central Banks Respond to Exchange Rate Movements: A Structural Investigation", Journal of Monetary Economics, 54: 1069-1087.

[31] Monacelli, T., (2005), "Monetary Policy in a Low Pass-Through Environment", Journal of Money Credit and Banking, vol 37, 1047-1066.

[32] Rotemberg, Julio J., and Michael Woodford (1996), "Imperfect Competition and the Effects of Energy Price Increases," Journal of Money, Credit, and Banking, 28 (part 1), pp. 549-577. 
[33] Rotemberg, Julio J., and Michael Woodford (1999), "Interest Rate Rules in an Estimated Sticky Price Model", in J. B. Taylor (ed.) Monetary Policy Rules (Chicago: University of Chicago Press).

[34] Yilmazkuday, Hakan, (2009), "Is there a Role for International Trade Costs in Explaining the Central Bank Behavior", MPRA Working Paper No 15951.

\section{Appendix A: Derivation of the Model}

The model is a modified and simpler version of Gali and Monacelli's (2005) open-economy model with the addition of international transport costs as presented in Yilmazkuday (2009). ${ }^{2}$ It is a continuum of goods model in which all goods are tradable, the representative individual holds assets, and the production of goods requires labor input. Subscripts $H$ and $F$ stand for domestically and foreign-produced goods, respectively. Superscript $*$ stands for the variables of the foreign country (i.e., rest of the world). A bar on a variable $(-)$ stands for a target value. Lower case letters denote log variables. Capital letters without a time subscript denote steady-state values.

\subsection{Individuals}

The representative individual in the domestic (i.e., home) country has the following intertemporal lifetime utility function:

$$
E_{t}\left[\sum_{k=0}^{\infty} \beta^{k}\left\{U\left(C_{t+k}\right)-V\left(N_{t+k}\right)\right\}\right]
$$

where $U\left(C_{t}\right)$ is the utility out of consuming a composite index of $C_{t}, V\left(N_{t}\right)$ is the disutility out of working $N_{t}$ hours, and $0<\beta<1$ is a discount factor. The composite consumption index $C_{t}$ is

\footnotetext{
${ }^{2}$ The model of this paper slightly deviates from Yilmazkuday (2009) by assuming a zero-trend inflation, because all variables are represented as percentage deviations from their steady-states in this paper.
} 
defined by:

$$
C_{t}=\left(C_{H, t}\right)^{1-\gamma}\left(C_{F, t}\right)^{\gamma}
$$

where $C_{H, t}$ and $C_{F, t}$ are consumption of home and foreign (i.e., imported) goods, respectively, and $\gamma$ is the share of domestic consumption allocated to imported goods. These symmetric consumption sub-indexes are defined by:

$$
C_{H, t}=\left[\int_{0}^{1} C_{H, t}(j)^{(\theta-1) / \theta} d j\right]^{\theta /(\theta-1)} \text { and } C_{F, t}=\left[\int_{0}^{1} C_{F, t}(j)^{(\theta-1) / \theta} d j\right]^{\theta /(\theta-1)}
$$

where $C_{H, t}(j)$ and $C_{F, t}(j)$ represent domestic consumption of home and foreign good $j$, respectively, and $\theta>1$ is the price elasticity of demand faced by each monopolist. The optimality conditions result in:

$$
\begin{aligned}
& C_{H, t}(j)=\left[\frac{P_{H, t}(j)}{P_{H, t}}\right]^{-\theta} C_{H, t} \\
& C_{F, t}(j)=\left[\frac{P_{F, t}(j)}{P_{F, t}}\right]^{-\theta} C_{F, t}
\end{aligned}
$$

where $P_{H, t}(j)$ and $P_{F, t}(j)$ are prices of domestically consumed home and foreign good $j$, respectively. $P_{H, t}$ and $P_{F, t}$ are price indexes of domestically consumed home and foreign goods, respectively, which are defined as:

$$
P_{H, t}=\left[\int_{0}^{1}\left(\left[P_{H, t}(j)\right]\right)^{1-\theta} d j\right]^{1 /(1-\theta)}
$$

and

$$
P_{F, t}=\left[\int_{0}^{1}\left(\left[P_{F, t}(j)\right]\right)^{1-\theta} d j\right]^{1 /(1-\theta)}
$$

Similarly, the demand allocation of home and imported goods implies:

$$
C_{H, t}=\frac{(1-\gamma) C_{t} P_{t}}{P_{H, t}}
$$

and

$$
C_{F, t}=\frac{\gamma P_{t} C_{t}}{P_{F, t}}
$$


where $P_{t}=\left(P_{H, t}\right)^{1-\gamma}\left(P_{F, t}\right)^{\gamma}$ is the consumer price index (CPI). The log-linear version of CPI can be written as:

$$
p_{t} \equiv(1-\gamma) p_{H, t}+\gamma p_{F, t}
$$

where $p_{H, t}$ and $p_{F, t}$ are logs of $P_{H, t}$ and $P_{F, t}$, respectively. The (log) price index for imported goods is further given by:

$$
p_{F, t}=e_{t}+p_{F, t}^{*}+\tau_{t}
$$

where $e_{t}$ is the $(\log )$ nominal effective exchange rate; $p_{F, t}^{*}$ is the (log) price index of domestically consumed foreign goods at the source; and $\tau_{t}$ is the (log) gross international transport cost, which is an income received by the rest of the world. ${ }^{3}$ The (log) gross international transport cost directly enters the price index for imported goods, because it is assumed that the international transport costs are the same across goods, and they are symmetric. The evolution of international transport costs is given by an $\mathrm{AR}(1)$ process:

$$
\tau_{t}=\rho_{\tau} \tau_{t-1}+\varepsilon_{t}^{\tau}
$$

where $\rho_{\tau} \in[0,1]$ and $\varepsilon_{t}^{\tau}$ is assumed to be an independent and identically distributed (i.i.d.) shock with zero mean and variance $\sigma_{\tau}^{2}$.

The $(\log )$ effective terms of trade is defined as $s_{t} \equiv p_{F, t}-p_{H, t}$, which implies that the $(\log )$ CPI formula can be written as:

$$
p_{t} \equiv(1-\gamma) p_{H, t}+\gamma p_{F, t}
$$

Combining $s_{t} \equiv p_{F, t}-p_{H, t}$ and $p_{F, t}=e_{t}+p_{F, t}^{*}+\tau_{t}$ results in an alternative expression for the (log)

\footnotetext{
${ }^{3}$ For future reference, $p_{H, t}^{*}$ is the $(\log )$ price index for the imported goods for the rest of the world, and $p_{F, t}^{*}$ is the (log) domestic price index for the rest of the world. We assume that the trade costs consist of transportation costs and transportation sector is owned by the rest of the world, so there is no transportation income received by the home country.
} 
effective terms of trade:

$$
s_{t} \equiv e_{t}+p_{F, t}^{*}+\tau_{t}-p_{H, t}
$$

which includes international transport costs.

The formula of CPI inflation follows as:

$$
\pi_{t}=\pi_{H, t}+\gamma\left(s_{t}-s_{t-1}\right)
$$

where $\pi_{t}=p_{t}-p_{t-1}$ is CPI inflation, and $\pi_{H, t}=p_{H, t}-p_{H, t-1}$ is the inflation of home-produced goods (i.e., home inflation). Combining Equations 6.13 and (6.14) results in an alternative expression of CPI inflation:

$$
\pi_{t}=(1-\gamma) \pi_{H, t}+\gamma\left(\pi_{F, t}^{*}+\Delta e_{t}+\Delta \tau_{t}\right)
$$

which suggests that CPI inflation is a weighted sum of home inflation, foreign inflation, growth in exchange rate, and growth in international transport costs. Hence, international transport costs play an important role in the determination of CPI inflation.

The individual household constraint is given by:

$$
\int_{0}^{1}\left[P_{H, t}(j) C_{H, t}(j)+P_{F, t}(j) C_{F, t}(j)\right] d j+E_{t}\left[F_{t, t+1} B_{t+1}\right]=W_{t} N_{t}+B_{t}+T_{t}
$$

where $F_{t, t+1}$ is the stochastic discount factor, $B_{t+1}$ is the nominal payoff in period $t+1$ of the portfolio held at the end of period $t, W_{t}$ is the hourly wage, and $T_{t}$ is the lump sum transfers/taxes.

By using the optimal demand functions, Equation (6.16) can be written in terms of the composite good as follows:

$$
P_{t} C_{t}+E_{t}\left[F_{t, t+1} B_{t+1}\right]=W_{t} N_{t}+B_{t}+T_{t}
$$

The representative home agent's problem is to choose paths for consumption, portfolio, and the labor supply. Therefore, the representative consumer maximizes her expected utility [equation 
(6.1)] subject to the budget constraint [equation (6.17)]. The first order condition implies that:

$$
\beta E_{t}\left[\frac{U_{C}\left(C_{t+1}\right) P_{t}}{U_{C}\left(C_{t}\right) P_{t+1}}\right]=\frac{1}{I_{t}}
$$

where $I_{t}=1 / E_{t}\left[F_{t, t+1}\right]$ is the gross return on the portfolio. Equation (6.18) represents the traditional intertemporal Euler equation for total real consumption. The labor supply decision of the individual is obtained as follows:

$$
\frac{W_{t}}{P_{t}}=\frac{V_{N}\left(N_{t}\right)}{U_{C}\left(C_{t}\right)}
$$

The problem is analogous for the rest of the world: Euler equation for the rest of the world is given by:

$$
\beta E_{t}\left[\frac{u_{C}^{*}\left(C_{t+1}^{*}\right) P_{t}^{*} \Xi_{t}}{u_{C}^{*}\left(C_{t}^{*}\right) P_{t+1}^{*} \Xi_{t+1}}\right]=E_{t}\left[F_{t, t+1}\right]
$$

where $\Xi_{t}$ is the nominal effective exchange rate. Combining Equations (6.18) and (6.20), together with assuming $U\left(C_{t}\right)=\log C_{t}$, one can obtain:

$$
C_{t}=C_{t}^{*} Q_{t}
$$

for all $t$, where $Q_{t}=\Xi_{t} P_{t}^{*} / P_{t}$ is the real effective exchange rate; thus, the (log) effective real exchange rate is obtained as:

$$
q_{t}=e_{t}+p_{t}^{*}-p_{t}
$$

By using Equations (6.9), (6.10) and (6.13), together with the symmetric versions of Equations (6.9) and (6.10) for the rest of the world, we can rewrite Equation (6.22) as follows:

$$
q_{t}=\left(1-\gamma-\gamma^{*}\right) s_{t}-\left(1-2 \gamma^{*}\right) \tau_{t}
$$

where $\gamma^{*}$ is the share of foreign consumption allocated to goods imported from the home country. Under the assumption of complete international financial markets, by combining log-linearized version of Equations (6.18), (6.20) and (6.21), together with Equation (6.22), the uncovered interest 
parity condition is obtained as:

$$
i_{t}=i_{t}^{*}+E_{t}\left[e_{t+1}\right]-e_{t}
$$

where $i_{t}=\log \left(I_{t}\right)=\log \left(1 /\left(E_{t}\left[F_{t, t+1}\right]\right)\right)$ is the home interest rate and $i_{t}^{*}=\log \left(\Xi_{t} /\left(E_{t}\left[F_{t, t+1} \Xi_{t+1}\right]\right)\right)$ is the foreign interest rate. This uncovered interest parity condition relates the movements of the interest rate differentials to the expected variations in the effective nominal exchange rate. Since $s_{t} \equiv e_{t}+p_{F, t}^{*}+\tau_{t}-p_{H, t}$ according to Equation (6.13), we can rewrite Equation (6.24) as follows:

$$
s_{t}=\left(i_{t}^{*}-E_{t}\left[\pi_{F, t+1}^{*}\right]\right)-\left(i_{t}-E_{t}\left[\pi_{H, t+1}\right]\right)+E_{t}\left[s_{t+1}-\Delta \tau_{t+1}\right]
$$

where $\Delta \tau_{t+1}$ is the change in trade cost from period $t$ to $t+1$. Equation (6.25) shows the terms of trade between the home country and the rest of the world as a function of current interest rate differentials, expected future home inflation differentials and its own expectation for the next period together with the expected future change in trade cost. Here, the evolution of foreign interest rate shock is given by:

$$
i_{t}^{*}=\rho_{i^{*}} i_{t-1}^{*}+\varepsilon_{t}^{i^{*}}
$$

where $\rho_{i^{*}} \in[0,1]$, and $\varepsilon_{t}^{i^{*}}$ is assumed to be an independent and identically distributed (i.i.d.) shock with zero mean and variance $\sigma_{i^{*}}^{2}$.

\subsection{Firms}

The representative domestic firm has the following production function:

$$
Y_{t}(j)=Z_{t} N_{t}(j)
$$

where $Z_{t}$ is an exogenous economy-wide productivity parameter; and $N_{t}$ is labor input. Accordingly, the marginal cost of production is given by:

$$
M C_{t}^{n}=(1-\omega) \frac{W_{t}}{Z_{t}}
$$


where $\omega$ is the employment subsidy. The inclusion of this subsidy is not arbitrary, because as discussed below, under the assumption of a constant employment subsidy $\omega$ that neutralizes the distortion associated with firms' market power, it can be shown that the optimal monetary policy is the one that replicates the flexible price equilibrium allocation in a closed economy.

Using Equation (6.19), together with assuming $V\left(N_{t}\right)=N_{t}$, the log-linearized real marginal cost can be written as follows: ${ }^{4}$

$$
m c_{t}=\log (1-\omega)+w_{t}-p_{H, t}-z_{t}
$$

Moreover, if the aggregate output in the home country is defined as $Y_{t}=\left[\int_{0}^{1} Y_{t}(j)^{(\theta-1) / \theta} d j\right]^{\theta /(\theta-1)}$, labor market equilibrium implies:

$$
N_{t}=\int_{0}^{1} N_{t}(j) d j=\frac{Y_{t} A_{t}}{Z_{t}}
$$

where $A_{t}=\int_{0}^{1} \frac{Y_{t}(j)}{Y_{t}} d j$ of which equilibrium variations can be shown to be of second-order in log terms. Thus, in first-order log-linearized terms, we can write:

$$
y_{t}=z_{t}+n_{t}
$$

where $z_{t}$ evolves according to:

$$
z_{t}=\rho_{z} z_{t-1}+\varepsilon_{t}^{z}
$$

where $\rho_{z} \in[0,1]$ and $\varepsilon_{t}^{z}$ is assumed to be an i.i.d. shock with zero mean and variance $\sigma_{z}^{2}$.

\subsection{Market Clearing}

For all differentiated goods, market clearing implies:

$$
Y_{t}(j)=C_{H, t}(j)+C_{H, t}^{*}(j)
$$

\footnotetext{
${ }^{4}$ Balanced growth requires the relative risk aversion in consumption to be unity, and thus we set $U(C)=\log C$ . Following the lead of Hansen (1985), we also assume that labor is indivisible, implying that the representative agent's utility is linear in labor hours so that $V(N)=N$.
} 
Using Equation (6.4), it can be rewritten as follows:

$$
Y_{t}(j)=\left[\frac{P_{H, t}(j)}{P_{H, t}}\right]^{-\theta} C_{H, t}^{A}
$$

where $C_{H, t}^{A}=C_{H, t}+C_{H, t}^{*}$ is the aggregate world demand for the goods produced in the home country. Using Equation (6.7) and the symmetric version of Equation (6.8) for the rest of the world, Equation (6.34) can be rewritten as follows:

$$
Y_{t}(j)=\left[\frac{P_{H, t}(j)}{P_{H, t}}\right]^{-\theta}\left((1-\gamma) \frac{P_{t} C_{t}}{P_{H, t}}+\gamma^{*} \frac{P_{t}^{*} C_{t}^{*}}{P_{H, t}^{*}}\right)
$$

Using $Y_{t}=\left[\int_{0}^{1} Y_{t}(j)^{(\theta-1) / \theta} d j\right]^{\theta /(\theta-1)}$, one can write:

$$
\begin{aligned}
Y_{t} & =\left((1-\gamma) \frac{P_{t} C_{t}}{P_{H, t}}+\gamma^{*} \frac{P_{t}^{*} C_{t}^{*}}{P_{H, t}^{*}}\right) \\
& =\left(\frac{P_{t}}{P_{H, t}}\right) C_{t}\left((1-\gamma)+\gamma^{*}\left(\frac{P_{t}^{*} P_{H, t}}{P_{t} P_{H, t}^{*}}\right) Q_{t}^{-1}\right)
\end{aligned}
$$

which implies that Equation (6.35) can be rewritten as follows:

$$
Y_{t}(j)=\left[\frac{P_{H, t}(j)}{P_{H, t}}\right]^{-\theta} Y_{t}
$$

Log-linearizing Equation (6.36) around the steady-state, together with using $s_{t} \equiv p_{F, t}-p_{H, t}$ and Equation (6.23), will transform it to the following expression:

$$
y_{t}=c_{t}+\gamma s_{t}-\tau_{t}
$$

Also using Equation (6.14) and the log-linearized version of Equation (6.18) (i.e., Euler), Equation (6.38) can be rewritten as follows:

$$
y_{t}=E_{t}\left(y_{t+1}\right)-\left(i_{t}-E_{t}\left(\pi_{H, t+1}\right)\right)+E_{t}\left(\Delta \tau_{t+1}\right)
$$

which represents an IS curve that considers the effect of international transport costs on output, which is not the usual case in the literature where the last term (i.e., the expected change in international transport costs) is absent. From another point of view, Equation (6.39) represents 
an IS curve that relates the expected change in (log) output (i.e., $\left.E_{t}\left(y_{t+1}\right)-y_{t}\right)$ to the difference between the interest rate, the expected future domestic inflation (i.e., an approximate measure of real interest rate that becomes an exact measure of real interest rate when the terms of trade are constant across periods), and the expected change in international transport $\operatorname{costs}^{5}$ An increase in the difference between the expected inflation and the nominal interest rate decreases the expected change in the output gap, with a unit coefficient. Finally, an expected increase in the international transport costs leads to a decrease in the expected change in (log) output. The latter is due to the intertemporal substitution of supply in response to a change in international transport costs.

The model employs a Calvo price-setting process, in which producers are able to change their prices only with some probability, independently of other producers and the time elapsed since the last adjustment. It is assumed that producers behave as monopolistic competitors. Accordingly, each producer faces the following demand function:

$$
Y_{t}(j)=\left[\frac{P_{H, t}(j)}{P_{H, t}}\right]^{-\theta} C_{H, t}^{A},
$$

where $C_{H, t}^{A}=C_{H, t}+C_{H, t}^{*}$ is the aggregate world demand for the goods produced. Note that this expression is the same with Equation (6.34).

Assuming that each producer is free to set a new price at period $t$, the objective function can be written as:

$$
\max _{\widetilde{P}_{H, t}} E_{t}\left[\sum_{k=0}^{\infty} \alpha^{k} F_{t, t+k}\left\{Y_{t+k}\left(\widetilde{P}_{H, t}-M C_{t+k}^{n}\right)\right\}\right]
$$

where $\widetilde{P}_{H, t}$ is the new price chosen in period $t$, and $\alpha$ is the probability that producers maintain the same price of the previous period. The problem of producers is to maximize equation (6.41) subject to Equation (6.40). The first order necessary condition of the firm for this maximization

\footnotetext{
${ }^{5}$ See Kerr and King (1996), and King (2000) for discussions on incorporating the role for future output gap in the IS curve with a unit coefficient.
} 
is:

$$
E_{t}\left[\sum_{k=0}^{\infty} \alpha^{k} F_{t, t+k}\left\{Y_{t+k}\left(\widetilde{P}_{H, t}-\zeta M C_{t+k}^{n}\right)\right\}\right]=0
$$

where $\zeta \equiv \theta /(\theta-1)$ is a markup as a result of market power. Using Equation (6.18), we can rewrite Equation (6.42) as follows:

$$
E_{t}\left[\sum_{k=0}^{\infty}(\beta \alpha)^{k} \frac{Y_{t+k}}{C_{t+k}} \frac{P_{H, t-1}}{P_{t+k}}\left\{\frac{\widetilde{P}_{H, t}}{P_{H, t-1}}-\zeta \Pi_{t-1, t+k}^{H} M C_{t+k}\right\}\right]=0
$$

where $\Pi_{t-1, t+k}^{H}=\frac{P_{H, t+k}}{P_{H, t-1}}$ and $M C_{t+k}=\frac{M C_{t+k}^{n}}{P_{H, t+k}}$.

Log-linearizing equation Equation (6.43) around trend inflation $\bar{\Pi}=1$ (i.e., zero inflation) together with balanced trade results in:

$$
\tilde{p}_{H, t}=\bar{\pi}+p_{H, t-1}+E_{t}\left[\sum_{k=0}^{\infty}(\beta \alpha)^{k} \pi_{H, t+k}\right]+(1-\beta \alpha) E_{t}\left[\sum_{k=0}^{\infty}(\beta \alpha)^{k} \widehat{m c}_{t+k}\right]
$$

where $\bar{\pi}=\log \bar{\Pi}=0 ; \widehat{m c}_{t}=m c_{t}-m c$ is the log deviation of real marginal cost from its steady state value, $m c=-\log \zeta$. Equation (6.44) can be rewritten as:

$$
\widetilde{p}_{H, t}-p_{H, t-1}=(1-\beta \alpha) \bar{\pi}+\beta \alpha E_{t}\left[\widetilde{p}_{H, t}-p_{H, t-1}\right]+\pi_{H, t}+(1-\beta \alpha) \widehat{m c}_{t}
$$

In equilibrium, each producer that chooses a new price in period $t$ will choose the same price and the same level of output. Then the (aggregate) price of domestic goods will obey:

$$
P_{H, t}=\left[\alpha P_{H, t-1}^{1-\theta}+(1-\alpha) \widetilde{P}_{H, t}^{1-\theta}\right]^{1 /(1-\theta)}
$$

which can be log-linearized as follows:

$$
\pi_{H, t}=(1-\theta)\left(\widetilde{p}_{H, t}-p_{H, t-1}\right)
$$

Finally, by combining Equations (6.45) and (6.47), we obtain the New-Keynesian Phillips curve:

$$
\pi_{H, t}=\beta E_{t}\left(\pi_{H, t+1}\right)+\lambda_{x} \widehat{m c}_{t}
$$

where $\lambda_{x}=\frac{(1-\alpha)(1-\alpha \beta)}{\alpha}$. 


\subsection{Equilibrium Dynamics}

Combining Equations (6.29) and (6.38) leads to an expression for real marginal cost in terms of output:

$$
m c_{t}=\log (1-\omega)+y_{t}-z_{t}+\tau_{t}
$$

By using the symmetric version of Equation (6.38) for the rest of the world, namely $y_{t}^{*}=c_{t}^{*}+$ $\gamma^{*} s_{t}^{*}-\tau_{t}$, together with Equations (6.23) and (6.21), one can obtain:

$$
y_{t}=y_{t}^{*}+s_{t}-\tau_{t}
$$

As discussed in Rotemberg and Woodford (1999), under the assumption of a constant employment subsidy $\omega$ that neutralizes the distortion associated with firms' market power, it can be shown that the optimal monetary policy is the one that replicates the flexible price equilibrium allocation in a closed economy. That policy requires that real marginal costs (and thus mark-ups) are stabilized at their steady state level, which in turn implies that domestic prices be fully stabilized. However, as shown by Gali and Monacelli (2005), there is an additional source of distortion in open economy models: the possibility of influencing the terms of trade in a way beneficial to domestic consumers. Nevertheless, an employment subsidy can be found that exactly offsets the combined effects of market power and the terms of trade distortions, thus rendering the flexible price equilibrium allocation optimal. In order to show this, consider the optimal allocation from the social planner's point of view: maximize Equation (6.1) subject to Equations (6.27), (6.30), (6.36) and (6.37). This optimization results in a constant level of employment, $N_{t}=1$, which is the first-best employment.

On the other hand, as in Gali and Monacelli (2005), flexible price equilibrium satisfies:

$$
\frac{\theta-1}{\theta}=\overline{M C}_{t}
$$

where $\overline{M C}_{t}$ stands for real marginal cost at flexible price equilibrium. If Equations (6.19), (6.28), 
(6.51) are combined with the optimal allocation of the social planner's problem (i.e., $N_{t}=1$ ), one can obtain:

$$
\frac{\theta-1}{\theta}=1-\omega
$$

which suggests that an employment subsidy can be found that exactly offsets the combined effects of market power and the terms of trade distortions.

After defining domestic natural level of output as the one satisfying flexible price equilibrium (i.e., Equation (6.49) with $m c_{t}=-\log \zeta$ ), it can be written as follows:

$$
\bar{y}_{t}=-\log \zeta-\log (1-\omega)+z_{t}-\tau_{t}
$$

which can be rewritten by using Equation (6.52) as follows:

$$
\bar{y}_{t}=z_{t}-\tau_{t}
$$

which suggests that the domestic natural level of output is negatively affected by international transport costs. This is mostly due to the allocation of some resources to the international transport costs.

Output gap can be defined as the deviation of (log) domestic output (i.e., $\left.y_{t}\right)$ from domestic natural level of output as follows:

$$
x_{t}=y_{t}-\bar{y}_{t}
$$

Using Equation (6.49), one can also write the (log) deviation of real marginal cost from its steady state in terms of output gap as $\widehat{m c}_{t}=x_{t}$, which implies that the New-Keynesian Phillips curve can be written in terms of output gap as follows:

$$
\pi_{H, t}=\beta E_{t}\left(\pi_{H, t+1}\right)+\lambda_{x} x_{t}
$$




\section{Appendix B: Divine Coincidence}

Blanchard and Gali (2007) have shown that when the gap between the natural level of output and the efficient (first-best) level of output is constant and invariant to shocks, stabilizing the output gap (the gap between actual and natural output) is equivalent to stabilizing the welfare-relevant output gap (the gap between actual and efficient output). This equivalence is the source of the divine coincidence: The NKPC implies that stabilization of inflation is consistent with stabilization of the output gap.

This section shows that there is no divine coincidence in the model of this paper. To see this, recall that $N_{t}=1$ (i.e., $n_{t}=0$ ) is the first-best allocation. Hence, under the first-best allocation, according to Equation 6.31, the first-best output would be given by:

$$
\bar{y}_{t}^{1}=z_{t}
$$

According to the flexible price equilibrium (i.e., the second-best allocation), it has been shown above that the second-best output is given by Equation 6.54:

$$
\bar{y}_{t}^{2}=z_{t}-\tau_{t}
$$

Hence, the difference between the first-best output and the second-best output is given by:

$$
\bar{y}_{t}^{1}-\bar{y}_{t}^{2}=\tau_{t}
$$

which is not invariant to shocks; i.e., stabilizing the output gap (the gap between actual and natural output) is not equivalent to stabilizing the welfare-relevant output gap (the gap between actual and efficient output). Hence, there is no divine coincidence in the model of this paper. 


\section{Appendix C: Foreign Output}

Combining Equations 6.25, 6.39 and 6.50 results in an IS equation for the foreign country:

$$
y_{t}^{*}=E_{t}\left(y_{t+1}^{*}\right)-\left(i_{t}^{*}-E_{t}\left(\pi_{F, t+1}^{*}\right)\right)+E_{t}\left(\Delta \tau_{t+1}\right)
$$

which is an expression for foreign output. Therefore, by considering shocks in the foreign financial

variable $f_{t}\left(=i_{t}^{*}-E_{t}\left(\pi_{F, t+1}^{*}\right)\right)$ and transport costs $\tau_{t}$, compared to earlier studies, the analysis of this paper decomposes the effects of foreign output shocks into foreign financial and transport costs shocks. When the version of the model with transport costs is considered, the effects of foreign output is expected to show up under either the foreign financial variable or transport costs, and when the version of the model without transport costs is considered, the effects of foreign output is expected to show up under the foreign financial variable.

\section{Appendix D: Financial Frictions}

If we remove the assumption of complete international financial markets, Euler equations for home and foreign countries (i.e., Equations 6.18 and 6.20) will not have the same right hand sides anymore; instead, the gross returns on the portfolios will be different from each other between the two countries. Such a financial friction would further appear in the uncovered interest parity (i.e., Equation 6.24). However, since we already assume that the foreign interest rate is determined through exogenous shocks, any financial friction or shock would be a part of the foreign interest rate shock as well. 
Table 1 - Prior Distributions

\begin{tabular}{|c|c|c|c|c|}
\hline Name & Domain & Density & Mean & Standard Deviation \\
\hline$\alpha$ & $\mathfrak{R}^{+}$ & Gamma & 0.5 & 0.25 \\
\hline$r$ & $\mathfrak{R}^{+}$ & Gamma & 2.5 & 1 \\
\hline$\chi_{\pi}$ & $\mathfrak{R}^{+}$ & Gamma & 1.5 & 0.25 \\
\hline$\chi_{x}$ & $\mathfrak{R}^{+}$ & Gamma & 0.25 & 0.13 \\
\hline$\gamma$ & {$[0,1)$} & Beta & 0.2 & 0.05 \\
\hline$\rho_{i}$ & {$[0,1)$} & Beta & 0.8 & 0.1 \\
\hline$\rho_{f}^{*}$ & {$[0,1)$} & Beta & 0.8 & 0.1 \\
\hline$\rho_{\tau}$ & {$[0,1)$} & Beta & 0.8 & 0.1 \\
\hline$\rho_{z}$ & {$[0,1)$} & Beta & 0.8 & 0.1 \\
\hline$\sigma_{i}$ & $\mathfrak{R}^{+}$ & InvGamma & 1 & 4 \\
\hline$\sigma_{f}^{*}$ & $\Re^{+}$ & InvGamma & 1 & 4 \\
\hline$\sigma_{\tau}$ & $\mathfrak{R}^{+}$ & InvGamma & 1 & 4 \\
\hline$\sigma_{z}$ & $\mathfrak{R}^{+}$ & InvGamma & 1 & 4 \\
\hline
\end{tabular}




\section{Figure 1 - Volatility of Oil Prices versus the Number of Recession Quarters}

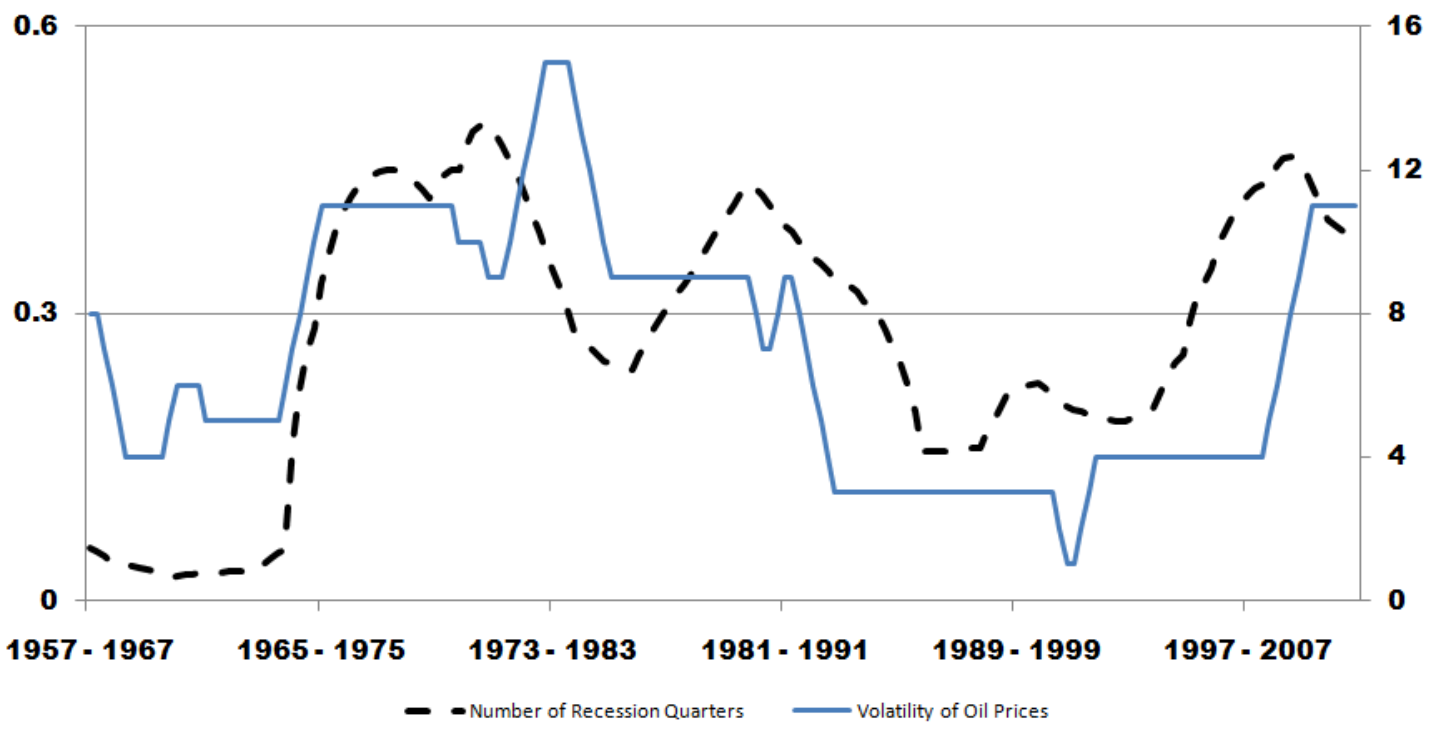

Notes: For each ten-year window, the dashed line and the vertical axis on the left represent the coefficient of variation for crude oil prices. For each ten-year window, the solid line and the vertical axis on the right represent the number of recession quarters according to NBER.

Figure 2 - Volatility of Oil Prices versus the Selected Model

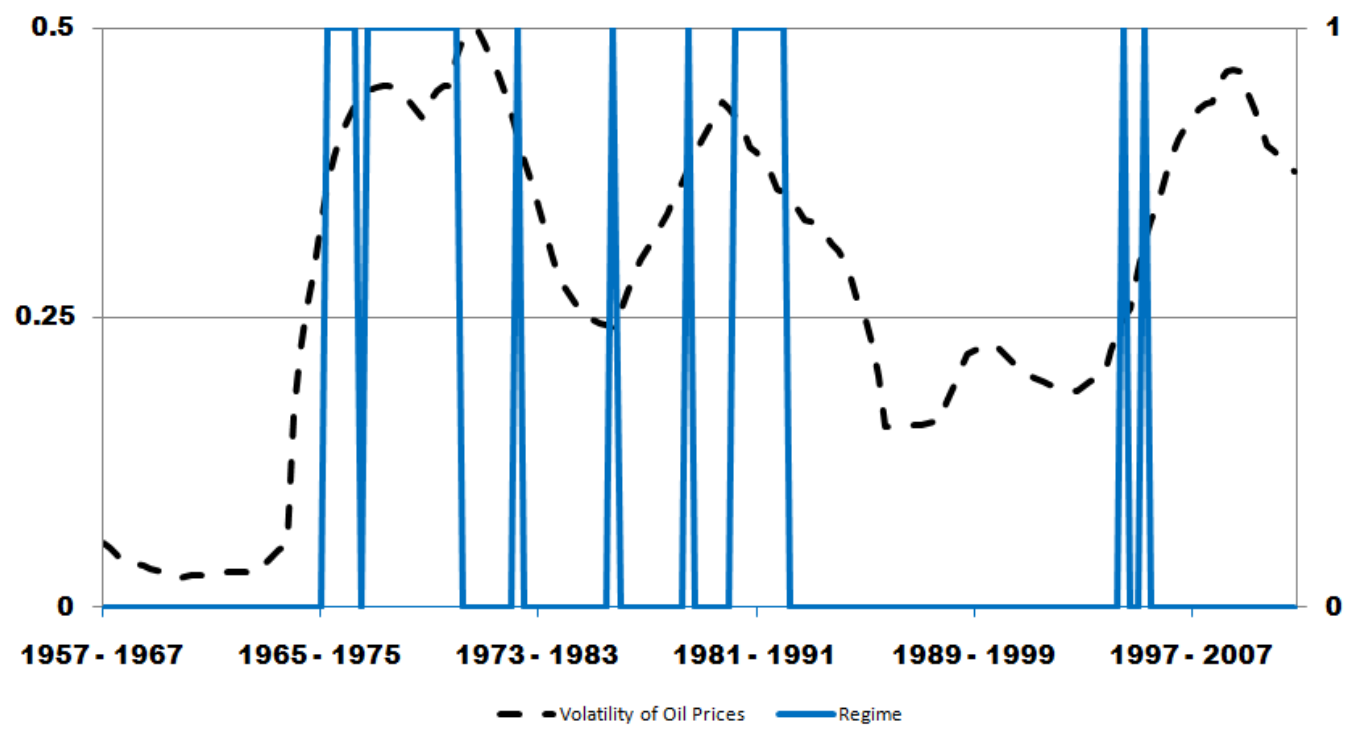

Notes: For each ten-year window, the dashed line and the vertical axis on the left represent the coefficient of variation for crude oil prices. For each ten-year window, the solid line and the vertical axis on the right represent the selected version of the model; 1 represents the version with international transport costs, and 0 represents the version without transport costs. 


\section{Figure 3 - Variance Decomposition of U.S. GDP with Transport Costs}

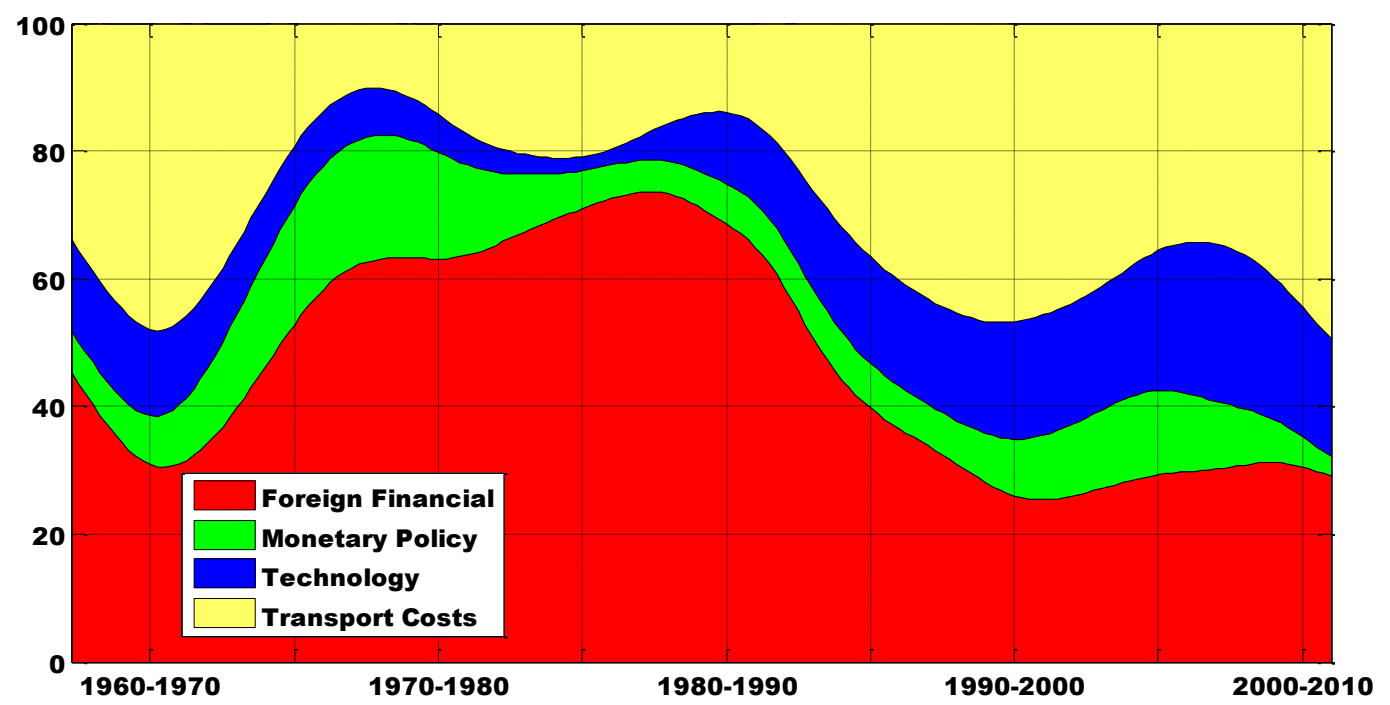

Notes: For each ten-year window, the colored areas show the HP filtered $(\lambda=1600)$ contribution of the relevant shocks on the volatility of U.S. GDP.

\section{Figure 4 - Variance Decomposition of U.S. GDP without Transport Costs}

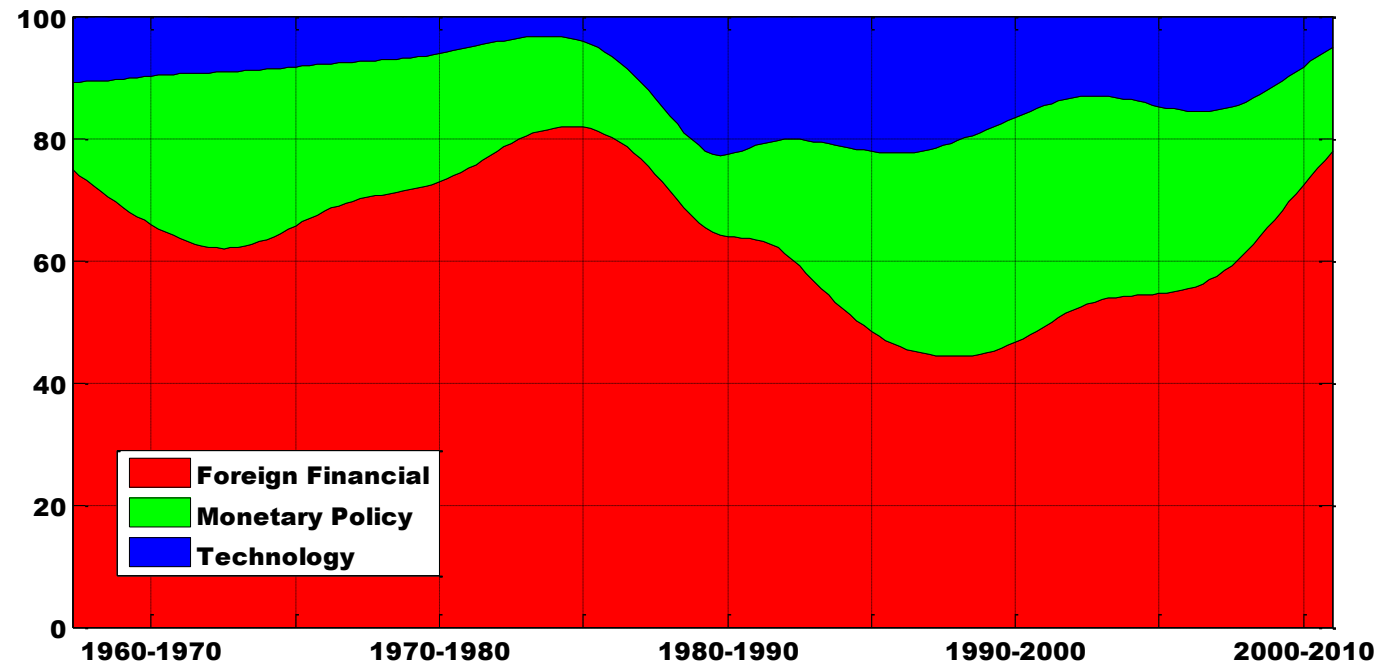

Notes: For each ten-year window, the colored areas show the HP filtered $(\lambda=1600)$ contribution of the relevant shocks on the volatility of U.S. GDP. 
Figure 5 - Combined Variance Decomposition of U.S. GDP

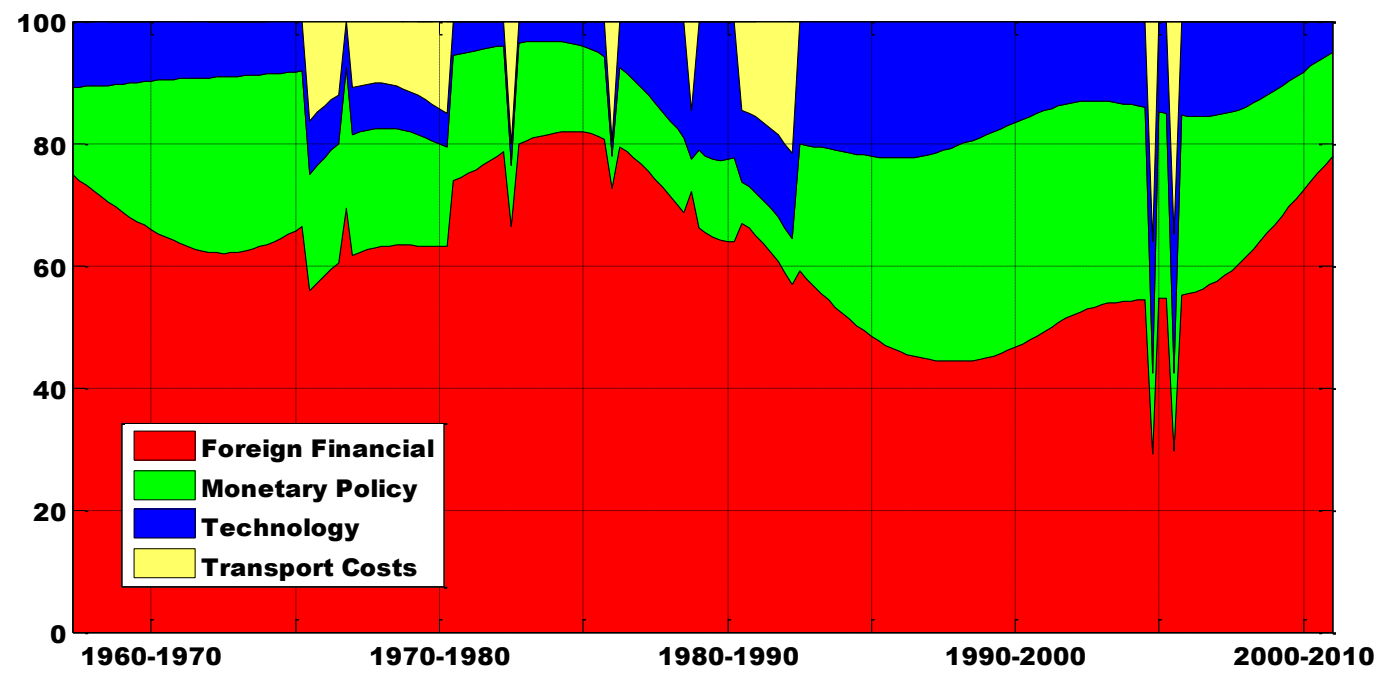

Notes: For each ten-year window, the colored areas show the HP filtered $(\lambda=1600)$ contribution of the relevant shocks on the volatility of U.S. GDP.

\section{Figure 6 - Volatility of Oil Prices versus Policy Response to Inflation}

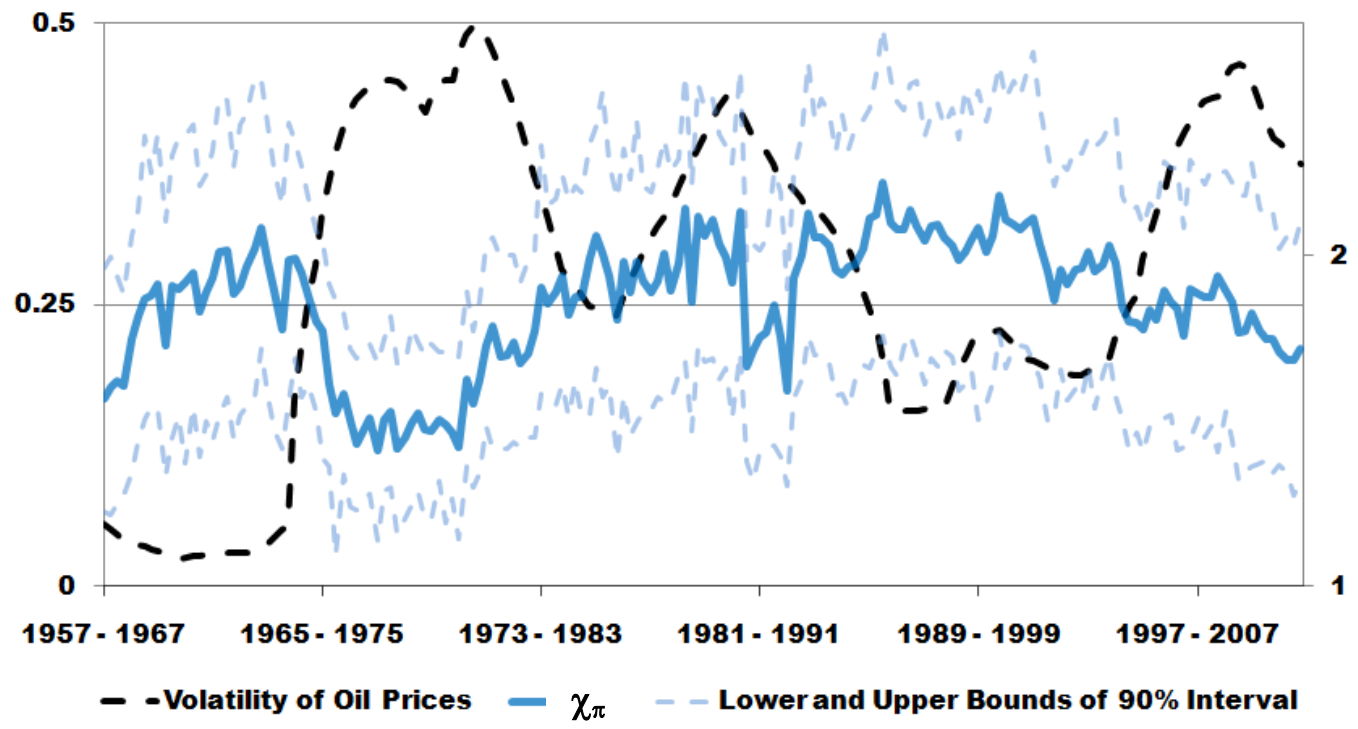

Notes: For each ten-year window, the dashed line and the vertical axis on the left represent the coefficient of variation for crude oil prices. For each ten-year window, the solid line and the vertical axis on the right represent the coefficient in front of inflation in the Taylor rule. The lighter dashed lines show the lower and upper bounds of $90 \%$ interval for the coefficient in front of inflation in the Taylor rule. 


\section{Figure 7 - Volatility of Oil Prices versus Policy Response to Output}

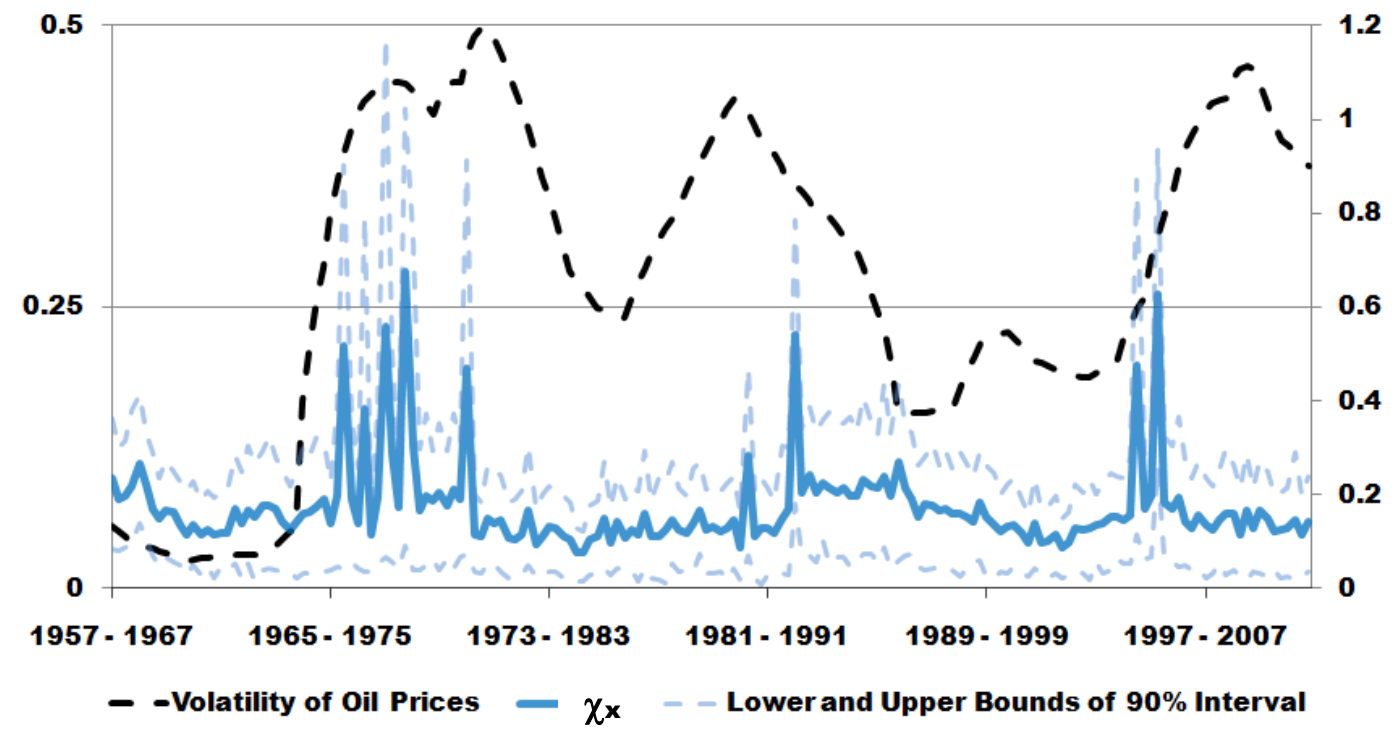

Notes: For each ten-year window, the dashed line and the vertical axis on the left represent the coefficient of variation for crude oil prices. For each ten-year window, the solid line and the vertical axis on the right represent the coefficient in front of output gap in the Taylor rule. The lighter dashed lines show the lower and upper bounds of $90 \%$ interval for the coefficient in front of output gap in the Taylor rule.

Figure 8 - Volatility of Oil Prices versus Interest Rate Smoothing

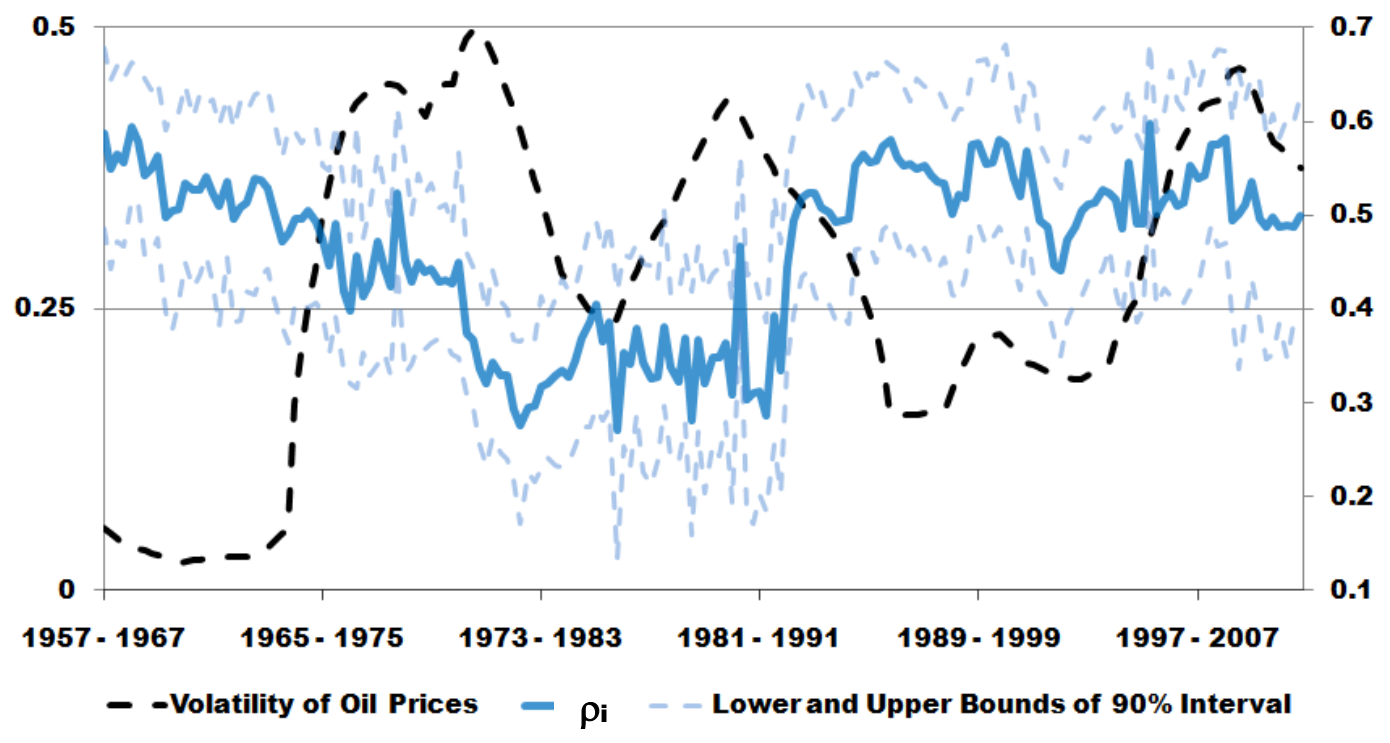

Notes: For each ten-year window, the dashed line and the vertical axis on the left represent the coefficient of variation for crude oil prices. For each ten-year window, the solid line and the vertical axis on the right represent the coefficient in front of lagged interest rate in the Taylor rule. The lighter dashed lines show the lower and upper bounds of $90 \%$ interval for the coefficient of lagged interest rate in the Taylor rule. 